\title{
ZAKAT DAN INFAQ DALAM MENGURANGI PATOLOGI KEMISKINAN ( STUDI PADA BAITUL MAL KOTA LANGSA)
}

\author{
Dr. Safwan Kamal, M.E.I \\ Dosen Fakultas Ekonomi dan Bisnis Islam IAIN Langsa
}

\begin{abstract}
Abstrak
Tujuan penelitian ini untuk mengetahui bagaimanakah konsep pengelolaan zakat dan infaq yang ada di Baitul Mal Kota Langsa dan Bagaimankah nilai-nilai motivasi ekonomi pada konsep tersebut dalam mengurangi patologi kemiskinan. Dengan pendekatan fenomenologi penelitian ini menemukan bahwa pengelolaan zakat dilakukan dalam mengurangi patologi kemiskinan dilakukan dalam bentuk produktif dengan mekanisme kepemilikan penuh, sedangkan infak dilakukan dalam bentuk program pembiayaan bergulir tanpa jaminan.Adapun nilai nilai motivasi ekonomi yang diwujudkan Amil melalui program zakat produktif adalah: Pertama: Membangun kedekatan emosional dengan mustahiq untuk terus berusaha. Kedua: Membangun tanggung jawab untuk meningkatkan status ekonomi. Ketiga: Membangun motivasi kerja. Keempat : Membangun kemandirian . Kelima: Membangun kepercayaa diri untuk menggapai keberhasilan dalam berusaha. Keenam: Membangun tangung jawab sosial pada masyarakat. Adapun nilai motivasi ekonomi yang diwujudkan melalui program infaq produktif adalah: Pertama :Membangun referensi usaha sebagai acuan untuk meningkatkan pendapatan. Kedua: Membangun relasi dengan member anjuran pada mustahik untuk mengikuti pelatihan da pembinaan bisnis. Ketiga :Membangun referensi pasar dalam mengembangkan usaha. Keempat :Membangun ideologi untuk membaca peluang-peluang bisnis baru dalam meningkatkan pendapatan.
\end{abstract}

Kata Kunci : Zakat, Infaq, Patologi Kemiskinan.

\section{PENDAHULUAN}

Perkembangan ekonomi saat ini melaju sangat cepat, konsep ekonomi tradisional mulai tergantikan dengan ekonomi konvensional bahkan ekonomi berbasis digital. Sayangnya banyak masyarakat yang berasal dari pedesaan belum mampu mengaplikasikan dan memanfaatkan ekonomi digital sebagai basis ekonomi global saat ini. Fenomena ini turut memperbesar jurang antara mereka yang menguasai modal dan digital dengan mereka yang hanya memperlakukan ekonomi sebagai sarana untuk mencukupi kebutuhan primer. 
Ihtiyath Vol. 2 No. 1 September 2018

Masyarakat yang tidak mampu memenuhi kebutuhan primernya termasuk masyarakat miskin. Kemiskinan merupakan permasalahan yang sangat krusial, dan bahkan pemerintahan dapat jatuh dikarenakan amukan masyarakat atas kemiskinan dan ketimpangan yang terjadi (Michael P.Todaro dan Stephen C. Smith: 2006). Secara umum kemiskinan yang dirasakan sering disebabkan oleh ketidaksetaraan pendapatan (Campbell, R. McConnell, : 1981).

Di tanah air, salah satu provinsi yang memiliki sejarah kemiskinan yang tinggi adalah Provinsi Aceh. Provinsi Aceh yang memiliki keistimewaan dalam mengelola perda "syariat Islam"dalam tatanan kehidupan masyarakat ternyata belum mampu mendongkrak perekonomiannya ke posisi yang lebih baik. Hal ini berbasis pada data BPS yang mencatat Aceh sebagai provinsi ke enam termiskin setelah Gorontalo dengan persentase 15,97\%.

Tabel. 1: Jumlah Penduduk Miskin di Provinsi Aceh periode Maret 2018

\begin{tabular}{c|c|c}
\hline No & Tahun & Jumlah penduduk \\
\hline 1 & 2014 & 837,42 \\
\hline 2 & 2015 & 859,41 \\
\hline 3 & 2016 & 841,31 \\
\hline 4 & 2017 & 829,80 \\
\hline 5 & 2018 & 839,49 \\
\hline
\end{tabular}

Sumber : Badan Pusat Statistik

Tabel. 2: Jumlah persentasi Penduduk Miskin 2018 periode Maret 2018

\begin{tabular}{|c|c|c|}
\multicolumn{1}{c}{ Peringkat } & \multicolumn{2}{c}{ Provinsi } \\
Papua & 27,24 \\
\hline 2 & Papua Barat & 23,01 \\
\hline 3 & Nusa Tenggara Timur & 21,35 \\
\hline 4 & Maluku & 18,12 \\
\hline 5 & Gorontalo & 16,81 \\
\hline 6 & Aceh & 15,97 \\
\hline
\end{tabular}

Sumber : Badan Pusat Statistik

Dalam rangka, mengungkap kasus penelitian, peneliti menggunakan salah satu Kab/Kota sebagai situs penelitian. Penelitian ini menetapkan Kota Langsa sebagai situs penelitian dikarenakan Kota Langsa memiliki persentase penduduk miskin yang cendrung menurun sejak tahun 2012-2015. 


\section{Grafik.1 : Persentase Penduduk Miskin Kota Langsa}

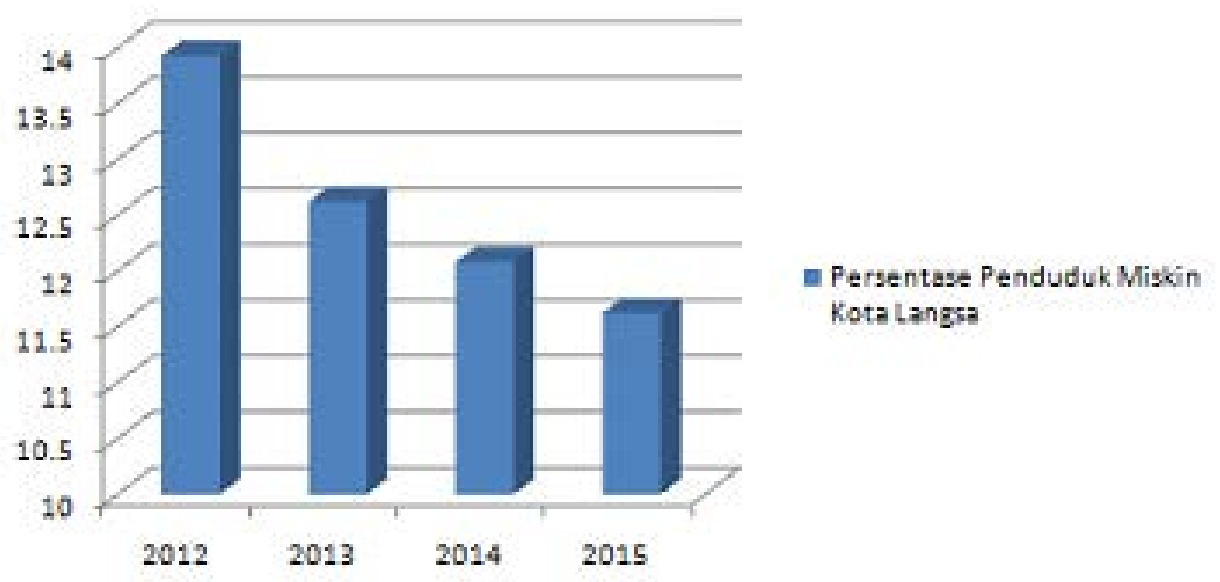

Sumber : BPS Kota Langsa 2018

Menurut Usman Abdullah (Wali Kota Langsa), salah satu sebab berkurangnya kemiskinan di kota Langsa disebebkan oleh peran Baitul Mal:

“...... selama ini kemiskinan yang terjadi di Kota Langsa berkurang disebabkan oleh banyak faktor, dan salah satunya adalah peran Baitul Mal yang sangat signifikan membantu pemerintah selama ini....."(Walikota Langsa)

Baitul Mal yang didirikan dan berada di Provinsi Aceh adalah lembaga non struktural yang di bentuk atas dasar qanun no 10 tahun 2007. Baitul Mal memiliki wewenang untuk mengelola dan mengembangkan zakat, wakaf dan harta agama lainnya untuk kemaslahatan umat. Definisi ini menjadi menarik dan searah dengan peta penelitia yang hendak membahas tentang Bagaimanakah konsep pengelolaan Zakat dan Infaq yang ada di Baitul Mal Kota Langsa? dan Bagaimankah nilai-nilai ekonomi pada konsep tersebut dalam mengurangi patologi kemiskinan?

\section{KAJIAN TEORI}

Baitul Mal terdiri dari kata bahasa Arab bait yang berarti rumah, dan al-mal yang memiliki makna harta. Istilah Baitul Mal berarti rumah yang digunakan untuk menyimpan harta/ kekayaan (A.Djazuli dan Yadi Janwari: 2002). 
Ihtiyath Vol. 2 No. 1 September 2018

Secara terminologis, Baitul Mal adalah suatu lembaga atau pihak yang mempunyai tugas khusus menangani harta umat, baik berupa pendapatan maupun pengeluaran negara (Harun Nasution, : 2002). Menurut Zallum, Baitul Mal adalah tempat penampungan dan pengeluaran harta, yang merupakan bagian dari pendapatan Negara (Abdul Qadim Zallum: 2006).

Definisi yang lain menerangkan bahwa Baitul Maal adalah rumah harta, gedung pembendaharaan Negara yang menyimpan sekian kekayaan harta Negara dan tempat pengaturan segala sesuatu yang bersangkutan dengan harta Negara tersebut. Pada zaman Rasulullah SAW pemungutan zakat dan lainnya sebagai sumber pendapatan Negara pada masa itu belum memerlukan administrasi yang luas, hal ini terjadi karena jumlah umat Islam yang masih terbatas (Abdul : 1997).

\section{Sejarah Baitul Mal Awal Periode Islam}

Baitul Mal mula-mula beroprasi pada saat kaum muslimin memperoleh ghanimah usai perang badar. Pada masa Rasulullah SAW., Baitul Mal merupakan lembaga yang menangani seluruh harta benda kaum muslimin (negara), baik pendapatan maupun pengeluarannya. Beberapa pendapatan yang masuk kedalam Baitul Mal terdiri dari zakat, kharaj, ushr, jizyah dan kafarat.

Baitul Mal terus berkembang seiring berkembangnya luasnya wilayah kekuasaan Islam pada masa pemerintahan khalifah Abubakar dan Umar. Pertumbuhan pendapatan Negarapun terus mengalami peningkatan. Pada masa kepemimpinan khalifah Umar dirasa perlu untuk menata kembali model pengelolaan Baitul Mal pada masa itu, adapun model pengelolaan yang digariskan pada masa itu adalah :

1. Harta Baitul Mal dikeluarkan secara bertahap sesuai dengan keperluan, Sebagian disediakan sebagai cadangan

2. Baitul Mal harus Independen dan pihak eksekutif tidak boleh ikut campur dalam pengelolaan Baitul Mal.

3. Pimpinan Baitul Mal memiliki otoritas penuh dalam mengelola harta Baitul Mal dan bertanggung jawab dalam pemerintah pusat.

4. Menyusun skala prioritas yang mendapat tunjangan sosial dari Baitul Mal (system diwan yang dibentuk oleh komite nassab), yang dimulai dengan orang-orang yang 
Safwan Kamal: Zakat dan Infaq

memiliki pertalian dengan Rasulullah SAW (kelompok as-shabiqun al awwalun dan seterusnya) kaum wanita, anak-anak dan kaum budak.

Pada masa Bani Umayah kedudukan Baitul Mal telah menjadi dua bagian, yaitu bagian umum dan khusus. Pendapatan Baitul Mal umum diperuntukkan bagi seluruh masyarakat umum, sedangkan pendapatan Baitul Mal khusus diperuntukkan bagi shulthan dan keluarganya.

Pada masa khalifah Umar Ibn Abdul Azis Baitul Mal ditertibkan kembali dengan memberikan pengumuman kepada seluruh kaum muslimin untuk menyerahkan harta yang tidak wajar yang dimiliki kepada Baitul Mal. Mulai dari Tanah perkebunan di Maroko, berbagai tunjangan yang diperoleh dari Yannamal, Mukaedah, Jabal Al Wars, Yaman dan Fadah serta cincin berlian yang diberikan oleh al-Walid. Disamping itu ia juga tidak mengambil suatu apapun dari Baitul Mal termasuk fa'i yang menjadi haknya. Prioritas pembangunan diarahkan kedalam negeri, karena dinilai lebih banyak dari pada perluasan wilayah. Baitul Mal sebagai lembaga keuangan Negara pada Masa Umar Ibn Abdul Azis mengalami masa keemasan. Hal ini ditandai dengan tidak adanya masyarakat yang menerima zakat (Amrullah : 2010).

\section{KONSEP ZAKAT DAN INFAQ}

Menurut Yusuf Qardhawi arti zakat dibagi menjadi dua yaitu menurut bahasa (lughah) dan menurut syara' (hukum fikih), menurut bahasa (lughah) zakat adalah suci, bersih, tumbuh, bertambah, berkah dan terpuji. Sedangkan menut syara' (hukum fiqih) bermakna pemberian yang wajib diberikan dari harta tertentu, menurut sifat-sifat dan ukuran tertentu kepada golongan tertentu (Yusuf Qardhawi: 1999). Menurut masdar, zakat adalah harta yang wajib dikeluarkan oleh Muzakki sesuai dengan ketentuan Syariat untuk diberikan kepada yang berhak menerimanya (Masdar Mas'udi : 1991). Definisi yang senada diutarakan oleh Sayyid Sabiq dimana zakat adalah bagian hak Allah SWT yang diberikan oleh manusia kepada orang-orang miskin. Dinamakan zakat, karena mengandung harapan mendapat berkah, penyucian diri dan tambahan kebaikan. Kata dasar zakat adalah Az- Zaka yang berarti berkembang, suci dan berkah (Sayyid Sabiq: 2000).

Infaq adalah mengeluarkan sebahagian harta benda yang dimiliki untuk kepentingan yang mengandung kemaslahatan. Dalam infak tidak ada nishab. Karena itu, infak boleh 
Ihtiyath Vol. 2 No. 1 September 2018

dikeluarkan oleh orang yang memiliki penghasilan tinggi maupun rendah, di saat lapang maupun sempit (M. Syafi'I El-Bantanie : 2009). Sebagaimana dalam Alquran surah Ali Imran ayat 134 (yaitu) “..orang-orang yang menafkahkan (hartanya), baik di waktu lapang maupun sempit, dan orang-orang yang menahan amarahnya dan mema'afkan (kesalahan) orang. Allah menyukai orang-orang yang berbuat kebajikan.."

\section{Patologi Kemiskinan}

Patologi berasal dari kata "Pathology" yang berarti ilmu yang mempelajari tentang penyakit (Yose dan David :2004). Istilah Patologi kemiskinan mengarah pada patologi sosial yang berarti ilmu tentang penyakit yang ada di masyarakat. Oleh sebab itu, kemiskinan meruapakan salah satu penyakit sosial yang mesti dihidari bahkan dalam Islam kemiskinan dapat memperburuk kondisi seseorang bahkan hingga rela menggadaikan iman.

Kemiskinan sebagai suatu kondisi juga dianggap sebagai masalah sosial karena menimbulkan berbagai penderitaan dan kerugian baik fisik maupun non fisik (Soetomo, : 2015). Raab dan Selznick menyatakan bahwa tidak semua masalah dalam kehidupan manusia merupakan masalah sosial. Masalah sosial pada dasarnya adalah masalah yang terjadi dalam antar hubungan diantara warga masyarakat. Weinberg dalam the solution of social problems menjelaskan bahwa masalah sosial adalah situasi yang dinyatakan sebagai suatu yang bertentangan dengan nilai-nilai oleh warga masyarakat yang cukup signifikan, dimana mereka sepakat dibutuhkannya suatu tindakan untuk mengubah situasi tersebut (Weinberg, Martin : 1981).

\section{Pengertian Kemiskinan dan Penyebab Kemiskinan}

Penduduk miskin adalah penduduk yang memiliki rata-rata pengeluaran perkapita perbulan di bawah garis kemiskinan (www. Bps.go.id:2018). Istilah kemiskinan atau masyarakat miskin merupakan istilah yang umum di pergunakan, sedangkan di dalam Islam ketidakmampuan seseorang dapat dipilah menjadi dua bahagian yaitu fakir dan miskin, meski demikian menurut Abu Yusuf dan Ibnu Qasim kedua golongan tersebut sama saja dan memiliki karakteristik yang sama (Yusuf Qardhawi : 2002).

Dari sudut pandang etimologi, kata miskin merupakan asal kata dari “as-sakan” yang berarti bahwa hal yang selalu bergolak atau bergerak. Ibnu Faris berkata "huruf sin, kaf, 
Safwan Kamal: Zakat dan Infaq

dan nun adalah huruf-huruf yang asli dan umum yang menandakan pada suatu makna kebalikan dari hal yang bergerak dan bergolak. Menurut Ibnu Faris orang miskin merupakan orang yang ditenangkan oleh kefakiran dan ia adalah orang yang sama sekali tidak memiliki apa-apa atau orang yang memiliki sesuatu tetapi tidak mencukupi kebutuhannya (Ibnu Faris: 1999). Seseorang dikatakan miskin dapat disebabkan oleh menaruh kepercayaan kepada orang lain atau karena kefakiran benar-benar telah membuat geraknya menjadi sedikit lalu mencegahnya untuk bergerak (Mahmud al-Athrasy : 2011).

\section{Bahaya Patologi Kemiskinan}

Setiap kelompok masyarakat memiliki "kaidah" yang secara luas memiliki pandangan tentang cara-cara yang tepat untuk mengatur kehidupan pribadi, bisnis dan aktivitas pemerintah (Takashi Inoguchi). Kemiskinan sebagai salah satu persoalan tentu memberikan dampak yang luarbiasa terhadap kehidupan masyarakat baik dalam hal pribadi, bisnis dan aktivitas pemerintah, dampak tersebut yaitu, membahayakan akidah, Kemiskinan membahayakan akhlak dan moral, Kemiskinan Mengancam Kestabilan Pemikiran (Imam Musbikin, : 2004).

Fenomena kemiskinan bukan persoalan yang berdiri sendiri melainkan persoalan yang muncul atas dasar sebab dan akibat. Menurut Ridwan kemiskinan dibagi menjadi dua kategori yaitu dari sisi pendapatan yang meliputi kemiskinan relative dan kemiskinan absolute. kedua sisi tersebut mencakup kemiskinan natural, kemiskinan kultural dan kemiskinan struktural (Muhammad Ridwan Mas'ud : 2005).Hal senada juga diutarakan oleh Rustanto, terdapat beberapa bentuk-bentuk kemiskinan yang sekaligus menjadi faktor penyebab kemiskinan (asal mula kemiskinan), seperti: kemiskinan natural, kemiskinan kultural dan kemiskinan structural (Bambang Rustanto: 2015).

\section{METODOLOGI PENELITIAN}

Penelitian ini menggunakan metode kulitatif dengan pendekatan fenomenologi, Menurut Darren Langdridge fenomenologi (senyawa dari kata Yunani phainomenon dan logos) yaitu mempelajari pengalaman manusia dan cara di mana hal-hal dirasakan seperti mereka tampak sadar (Darren Langdridge : 2007). tujuan penggunaan metode ini untuk menangkap kedua tujuan penelitian yaitu melihat konsep penerapan zakat dan Infaq secara produktif yang di aplikasikan pada Baitul Mal Kota Langsa serta menangkap nilai- 
Ihtiyath Vol. 2 No. 1 September 2018

nilai ekonomi yang dibangun terhadap mustahiq. Informan penelitian telah di tentukan dan diangap mampu menjawab persoalan penelitian.

Tabel.3 : Detail Informan

\begin{tabular}{lllll}
\hline Informan & Nama & Tempat Tinggal & Kota & Status \\
\hline I & $\begin{array}{l}\text { Alamsyah Abu- } \\
\text { bakardin }\end{array}$ & Matang Seulimeng & Langsa & Kepala \\
\hline II & Syahrun, S.H.I & Pondok Pabrik & Langsa & $\begin{array}{l}\text { Kepala Bagian } \\
\text { Penyaluran dan } \\
\end{array}$ \\
& & & & $\begin{array}{l}\text { Pendayagunaan } \\
\text { Zakat dan Infaq }\end{array}$ \\
& & & & Kepala Bagian \\
& & & Lengumpulan \\
III & Tgk. Herman- & Pondok Pabrik & & Zakat dan Infaq \\
\hline
\end{tabular}

\section{HASIL PENELITIAN DAN PEMBAHASAN}

\section{Konsep pengelolaan Zakat Produktif Baitul Mal Langsa}

Kosep pengelolaan zakat secara produktif dilakukan dengan konsep kepemilikan penuh sebagaimana di utarakan oleh informan I bahwa “..menurut pandangan saya selama ini memang kita menjadikan zakat itu kepemilikan penuh, jika ada mustahiq yang menginginkan bantuan usaha kami menggunakan dulu dari dana zakat sebagai uji coba, kami tidak meminta uang itu kembali karena konsep zakat itu sendiri dimiliki oleh mustahiq..."

Dilihat dari sisi penyaluran dana zakat produktif, informan II menjelaskan bahwa : “... penyaluran zakat produktif itu terbagi atas dua, ada yang kami berikan uang tunai dan ada juga yang kami berikan dalam bentuk barang, jika ia meminta dalam bentuk barang untuk usaha selama ini kami mendampinginya untuk membeli barang tersebut. Tujuannya adalah mustahiq dapat benar-benar mengunakan dana tersebut untuk kepentingan usaha...".

Dari sisi pemanfaatan dana zakat produktif infaq produktif informan I menyatakan: “..... mustahiq tidak terbebani dengan dana tersebut, karena dana tersebut mutlaq menjadi miliknya dan tidak harus pusing untuk mengembalikan dana tiap bulan...."

Beberapa narasi di atas, Baitul Mal kota langsa memanfaatkan sebagian dana yang bersumber dari zakat untuk kegiatan produktif. Penyaluran dilakukan dalam bentuk uang maupun barang untuk usaha/produksi. Modal ini juga sangat tidak memberatkan 
mustahik karena tidak adanya pengembalian kepada Baitul Mal Langsa.

\section{Gambar : 1}

\section{Konsep Pengelolaan Zakat Produktif Baitul Mal Langsa}

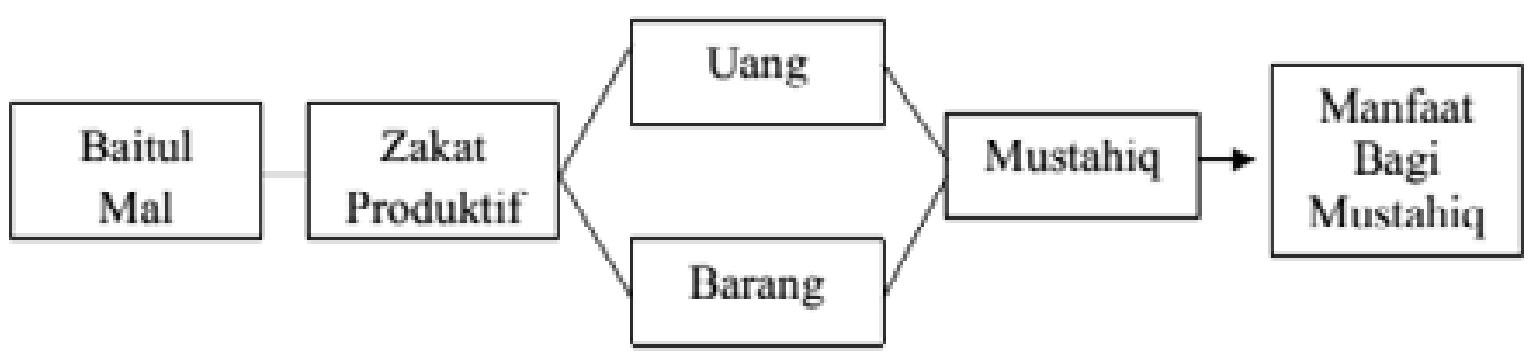

\section{Konsep pengelolaan Infaq Produktif Baitul Mal Langsa}

Disamping program zakat produktif, Baitul Mal kota Langsa mengembangkan juga program Infaq produktif, disebut sebagai Infaq Produktif karena bersumber dari dana infaq yang terkumpul dari masyarakat Kota Langsa. Menurut Informan II:

“... program nfaq produktif adalah program lanjutan dari program zakat produktif dengan skim/ alur pembiayaan yang berbeda. Artinya kami menginterventarisir dulu mustahiq yang meminjam dana infaq dengan melihat pengembangan stimulus dana zakat (tarck record mustahiq). Jika usahanya sudah agak berkembang dengan dana zakat dan diperlukan bantuan lagi untuk kemperluan usaha maka kami gunakan dana infaq. Mengunakan dana infaq kami bantu maksimal 5 juta dan yang berbasis kelompok pernah kami bantu 20 juta...."

Informan III menjelaskan bahwa: “... Program infaq produktif tidak sama dengan zakat produktif, jika infaq produktif memang itu sifatnya pembiayaan sama seperti pembiayaan di bank yang harus dikembalikan, hanya saja tidak adanya bagi hasil apalagi bunga, sebab yang kami gunakan adalah dana umat..."

Mengenai bentuk penyaluran informan I menegaskan bahwa: " program infaq produktif kami berikan ada dalam bentuk uang tunai dan ada pula dalam bentuk barang, tetapi lebih banyak dalam bentuk uang, kami juga mensyaratkan dana ini dikembalikan agar dapat membantu mustahik yang lain.." 
Ihtiyath Vol. 2 No. 1 September 2018

Berdasarkan narasi di atas, pengelolaan infaq produktif dilakukan Baitul Mal sebagai lanjutan dari program zakat produktif. Mustahiq yang telah berkembang diberikan kesempatan untuk menambah modal mereka dengan melakukan pembiayaan Infaq produktif, meski tanpa jaminan mustahiq di syaratkan untuk mengembalikan dana infaq produktif dalam jangka waktu yang ditentukan/ disepakati agar dana infaq produktif dapat di gulirkan ke pihak lain.

\section{Gambar : 2}

\section{Konsep Pengelolaan Infak Produktif Baitul Mal Langsa}

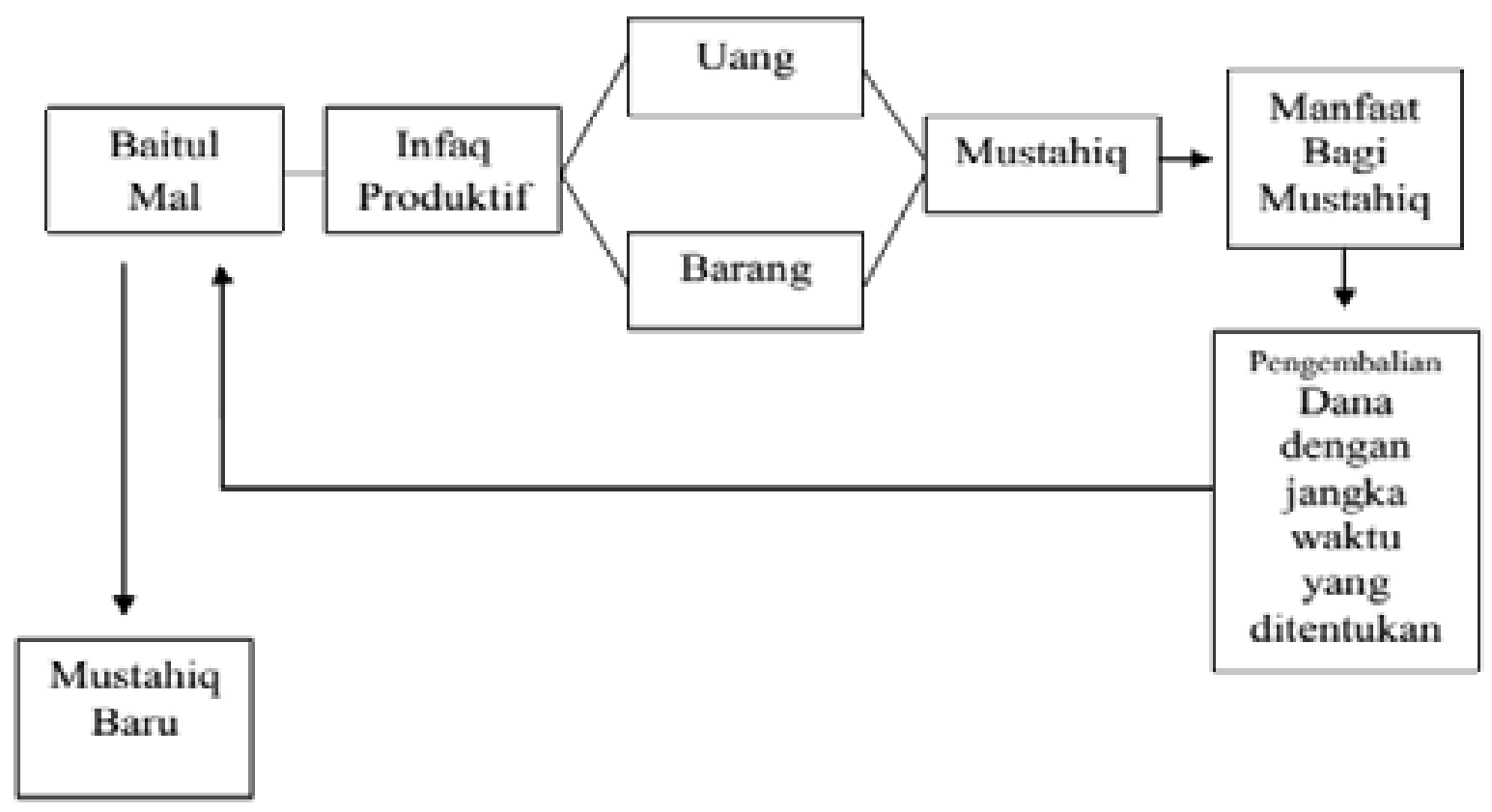

Nilai Motivasi Ekonomi dari penerapan Konsep pengelolaan Zakat Produktif Baitul Mal Langsa

Menurut Informan III, “ dana zakat uang kami berikan di awal harapannya bisa membantu mereka, jika yang memmng yang memohon bantuan itu dari golongan mustahik zakat maka kami bantu dia dulu dengan dana zakat. Agar ada hubungan awal antara mustahik dan amil di Baitul Mal Langsa, eonomi mereka kan lemah jadi kadang kami pun memberikan motivasi untuk tetap berusaha dan kamipun membantu semampu kami, ya kadang kami bilang, dengan kondisi eonomi seperti ini kita memang harus berusaha pak, ya tetap terus bekerja demi masa depan keluarga, apapun haslnya itu sudah ketentuan Allah, yang penting jangan berhenti berusaha..." 
Menurut Informan I, “... kondisi ekonomi sekarang memang lebih terasa sulit, bukan hanya mustahik saja, kadang orang yang sudah kita anggap mapan saja, punya kerja, pagkat, jabatan, masih terlilit hutang dimana-mana, oleh karenanya kami sangat berupaya membantu mereka untuk bias bertahan dalam masyarakat, jika tidak seseorang tentu dapat terjerumus dalam perbuatan amoral, mencuri dan sebagainya karena harus menutupi kebutuhan hidup...."

Narasi di atas mengisyaratkan bahwa nilai yang hendak dibangun amil bagi mustahik dana zakat produktif adalah:

Ekstraks informasi informan (Nilai zakat produktif : Nzp):

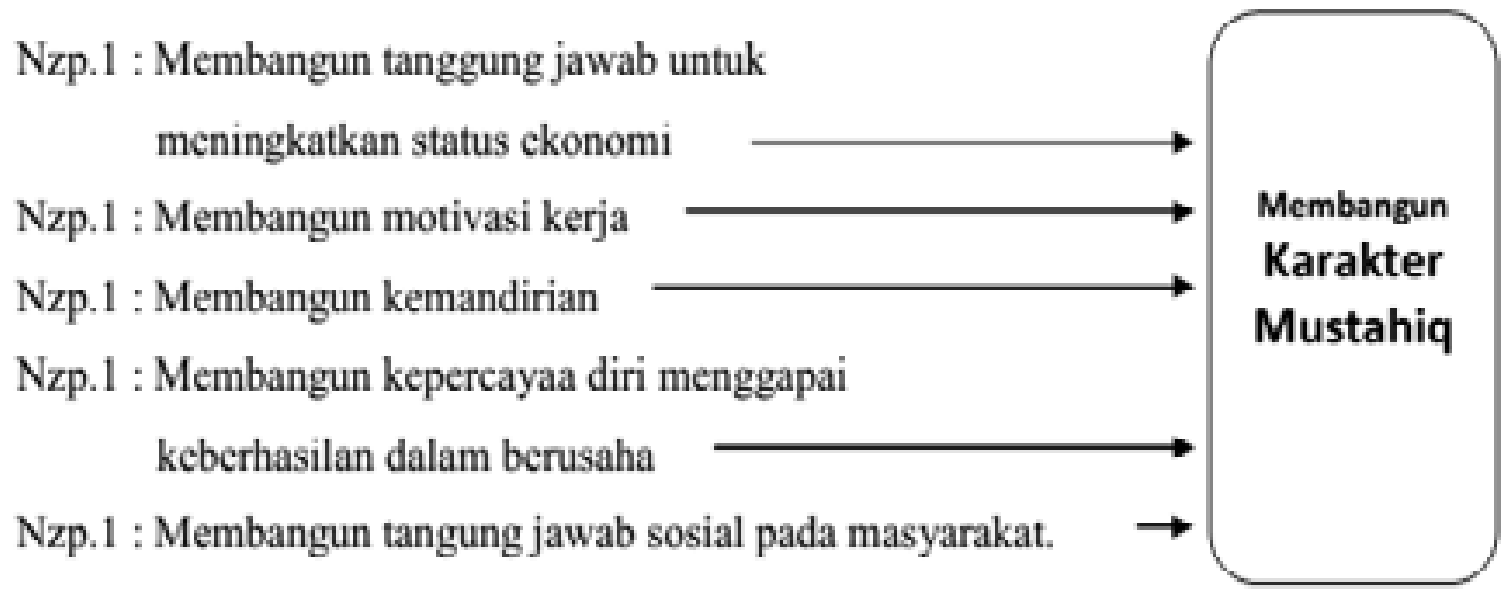

\section{Nilai Motivasi Ekonomi dari penerapan Konsep pengelolaan Infaq Produktif Baitul Mal Langsa.}

Baitul Mal mengembangkan Infaq produktif untuk meningkatkan pendapatan mustahik, disamping itu nilai nilai yang hendak dibagun dalam pemanfaatan dana infaq produktif yaitu:

Menurut informan II, “... selama ini yang sudah-sudah kami bantu ada beberapa yang kami silaturahim ketempat mereka, sambil silaturahim kamipun berdiskusi tentang hambatan dan peluang-peluang lain yang bias dikembangkan apa, agar usaha mereka semakin berkembang..."

Menurut informan III, “... disaat ada kesempatan kami juga menghimbau kepada mereka untuk turut aktif di gampong, karena sekarang banyak juga pelatihan-pelatihan bisnis 
Ihtiyath Vol. 2 No. 1 September 2018

yang diselenggarakan di gampong, jika memang nanti ada bisnis yang bias dikembangkan dan prospek pasarnya ada tentu kita bisa gunakan dana infaq untuk membantu..."

Ekstraks informasi informan (Nilai infaq produktif : Nip) :

Nip 1 : Membangun referensi usaha sebagai acuan untuk meningkatkan pendapatan

Nip 2 : Membangun relasi dengan mengikutsertakan mustahiq pada pelatihan dan pembinaan bisnis.

Nip 3 : Membangun referensi pasar dalam mengembangkan usaha.

Nip 4 : Membangun ideologi untuk membaca peluangpeluang bisnis baru dalam menngkatkan pendapatan.

Membangun

Motivasi

Pengambangan

Ekonomi

\section{KESIMPULAN}

Berdasarkan wawancara, observasi dan proses trianggulasi data, maka diperoleh bahwa :

1. Pengelolaan zakat dilakukan dalam bentuk produktif dengan mekanisme kepemilikan penuh. Zakat yang diberikan pada mustahiq dalam bentuk uang tunai atau harta benda siap pakai untuk terjunlangsung pada usaha mikro produktif. Mustahiq tidak dituntut untuk mengembalikan uang tunai atau harta yang telah ia terima meskipun usaha produktif yang ia lakukan gagal. Pengelolaan Infaq dan shadaqah dilakukan dalam bentuk pembiayaan bergulir. Infaq dan shadaqah yang diberikan pada mustahiq di harapkan di kembalikan oleh mustahiq dalam jangka waktu yang telah ditentukan. Infaq dan shadaqah produktif ini merupakan program kelanjutan dari keberhasilan mengelola zakat yang dapat dimanfaatkan oleh mustahiq

2. Adapun nilai nilai ekonomi yang diwujudkan melalui program zakat produktif adalah: Pertama: Membangun kedekatan emosional dengan mustahiq untuk terus berusaha. Kedua: Membangun tanggung jawab untuk meningkatkan status ekonomi. Ketiga: Membangun motivasi kerja. Keempat : Membangun kemandirian . Kelima: Membangun kepercayaa diri untuk menggapai keberhasilan dalam berusaha. Keenam: Membangun tangung jawab sosial pada masyarakat. 
Adapun nilai motivasi ekonomi yang diwujudkan melalui program infaq produktif adalah: Pertama:Membangun referensi usaha sebagai acuan untuk meningkatkan pendapatan. Kedua: Membangun relasi dengan mengikutsertakan mustahiq pada seminar, pelatihan da pembinaan bisnis. Ketiga:Membangun referensi pasar dalam mengembangkan usaha. Keempat:Membangun ideologi untuk membaca peluang-peluang bisnis baru dalam menngkatkan pendapatan.

\section{DAFTAR PUSTAKA}

A.Djazuli dan Yadi Janwari. (2002). Lembaga-lembaga Perekonomian Umat, Sebuah pengenalan. Jakarta: Raja Grafindo Persada.

Abdul Dkk. Kamus Istilah Fiqh . (1997). Kuala Lumpur : PT Pustaka Firdaus.

Abdul Qadim Zallum. (2006). Sistem keuangan di Negara khilafah. Bogor: Pustaka Thariqul Izzah.

Amrullah. (2010). Menggagas Ulang Tugas dan Fungsi Baitul Mal. Banda Aceh : Baitul Mal Aceh.

Badan Pusat Statistik Indonesia

Badan Pusat Statistik Kota Langsa

Bambang Rustanto. (2015). Menangani Kemiskinan .Bandung: Remaja Rosdakarya.

Campbell, R. McConnell. (1981). Economics, principles, Problems and Policies. America : McGraw-Hill.

Darren Langdridge. (2007). Phenomenological Theory, Research and method. England :Pearson Education.

Harun Nasution, et.al. (2002). Ensiklopedia Islam Indonesia. Jakarta: IAIN Syarif Hidayatullah.

Ibnu Faris. (1999). Mu’jam Maqayis al- Lughah. Beirut : Dār al-jail.

Imam Musbikin. (2004). Rahasia Puasa Bagi Kesehatan Fisik dan Psikis. Yogyakarta : Mitra Pustaka, 2004.

M. Syafi'I El-Bantanie. (2009). Zakat, Infaq dan sedekah. Bandung: Salamadani. 
Mahmud al-Athrasy. (2011). Hikmah di balik Kemiskinan. Jakarta: Qisthi Press.

Masdar Mas'udi. (1991). Agama Keadilan : Risalah zakat (pajak) dalam Islam. Jakarta: Pustaka Firdaus.

Michael P.Todaro dan Stephen C. Smith. (2006). Pembangunan Ekonomi. Jakarta: Erlangga.

Muhammad Ridwan Mas'ud. (2005). Zakat dan Kemiskinan, Instrumen pemberdayaan ekonomi umat. Yogyakarta: UII Press.

Sayyid Sabiq. (2000). Fiqih Sunnah. jilid 1. Jakarta, Al-l'tishom.

Soetomo, (2015). Masalah sosial dan upaya pemecahannya. Yogyakarta: Pustaka Pelajar.

Takashi Inoguchi, et.al. Kota dan Lingkungan. Jakarta: LP3ES.

Weinberg, Martin, at.al. (1981). the solution of social problems. New York: Oxford University Press.

Yose dan David. (2004). Kamus popular Kontemporer . Jakarta: Restu Agung.

Yusuf Qardhawi. (1999). Anatomi Masyarakat Islam, Cet.1. Jakarta: Pustaka Al-Kausar.

Yusuf Qardhawi. (2002). Hukum Zakat. Jakarta: Litera Antar Nusa. 